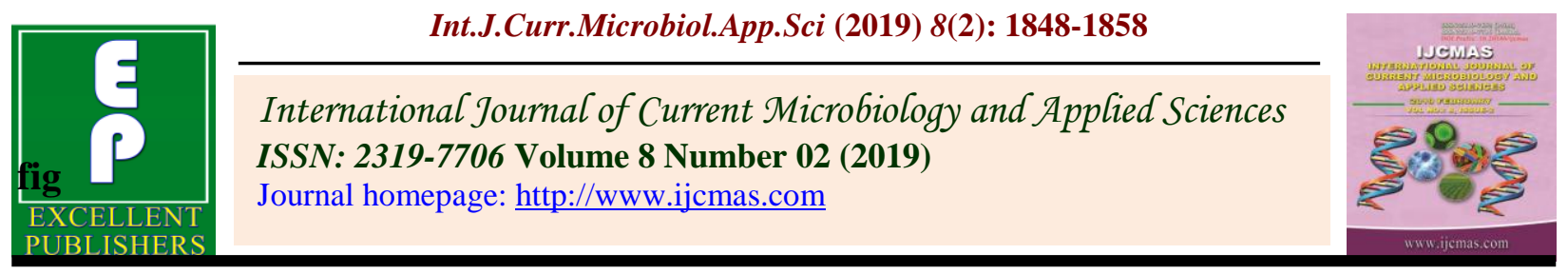

Original Research Article

https://doi.org/10.20546/ijcmas.2019.802.217

\title{
Effect of Hydrothermal Pre-Treatment on Snake Gourd Seed Shelling
}

\author{
D.O. Idowu ${ }^{1}$, S.A. Olaoye ${ }^{2}$, E.O. Owolabi ${ }^{3}$ and J.M. Adebayo ${ }^{4}$ \\ Department of Agricultural Engineering, Ladoke Akintola University of Technology, \\ Ogbomoso, Nigeria \\ *Corresponding author
}

\section{Keywords}

Hydrothermal,

Wetting time, Seed drying temperature, Shelling efficiency, Breakage percentage

Article Info

Accepted:

15 January 2019

Available Online:

10 February 2019

\section{A B S T R A C T}

Shelling is a fundamental unit operation during oil extraction of snake gourd seed oil. Lack of proper and efficient method of shelling the seed has been identifying as a major problem in the production and utilization of snake gourd seed oil. Currently manual method is popular which is cumbersome, time consuming and not efficient for the process. Seed pretreatment is required prior to shelling operation for some crops like snake gourd. Effect of hydrothermal pretreatment was evaluated on the shelling efficiency, percentage unshelled and percentage broken of the seed. The evaluations were done using a 2 by 3 by 5 factorial experiment. The two factors and their levels are soaking time $(10,20,30,40$, and 50 minutes) and seed drying temperature $\left(60,70,80,90\right.$, and $\left.100{ }^{\circ} \mathrm{C}\right)$. The result of the experiment shows that the highest shelling efficiency of $82.11 \%$ was achieved when the wetting time was 60 minutes and the seed drying temperature was $100{ }^{\circ} \mathrm{C}$ while the least efficiency $(47.4 \%)$ was recorded when the wetting time was 10 minutes and seed drying temperature was $60^{\circ} \mathrm{C}$. The highest percentage unshelled $(49.1 \%)$ was recoded at 10 minutes soaking time and $60^{\circ} \mathrm{C}$ seed drying temperature. It was observed that the broken percentage decreased from 11.9 to $6.15 \%$ as the drying temperature decrease from 100 to $60^{\circ} \mathrm{C}$. In conclusion, it was observed that the higher the soaking time and drying temperature the higher the shelling efficiency and the lower the unshell percentage.

\section{Introduction}

Snake gourd plant (Trichosanthes cucumerina L) is a tropical or subtropical vine that climbs up tree and unfurls the flowers and fruits to hang down to the ground (1). It is very popular in Asia, Africa, Australia, Europe, and South America (2). In Nigeria it is known as snake tomato, pathakaya in India, pakupis in Philippines, buapngu in Thailand, pudalanka in Tamil, paduvalakaayi in kannada and padavalanga in Malayam. The kernels contain soft endosperm which has been proved to be a good source of vegetable oil $(3 ; 4)$. Postharvest operation is an essential unit operation in an agricultural production and improves the usability of agricultural products. Removal of the seed coat from the kernel is very tedious when manual method is used. Shelling of oil bearing seed before oil expression has been proofed to be of great advantage like better quality and quantity of both raw oil (low wax content) and meal 
(higher protein content), and also increases the life span of the oil extraction machine (5; 6 and 7). (8) reported an increase in oil extracted from Jatropha curcas seed as the percentage of dehusk seed decreases. The treatment of some seed hydrothermally has been reported to improve their percentage of decortications. Many seeds like melon and sunflower seed decortications were carried out at a certain moisture content to have high decortications percentage (9). Shelling operation was found to depend on moisture content. (1)reported that as moisture content increased from 7 to $10 \%$ the shelling efficiency of melon seed shelling machine also increase from 45 to $99 \%$. Evaluation of shelling process of some industrial crops such as safflower (10) cotton seed (11), sunflower seed (12) and moringa seed (13) has been reported. However, the preliminary research has shown a great opportunity by using mechanical method after a hydrothermal pretreatment of the seed. Hydrothermal treatment involves soaking the seed in water for specific time and then dried it at a specified temperature. This method of pretreatment with varying degrees has been applied to some crops like millet (14) and rice (15).

In resent time, research work had been done on physical properties of snake gourd (16) and also effect of washing kernel on color and rheological property of snake gourd oil (3) but no work has been done on the effect of hydrothermal pretreatment on snake gourd decortication, hence, the study was done.

\section{Materials and Methods}

\section{Material sample collection}

The snake gourd seeds used were obtained from the Department of Agricultural Engineering, Ladoke Akintola University of Technology demonstration farm, Ogbomoso,
Nigeria. The seeds were clean to remove immature and damaged seeds before using them for the studies. A snake gourd sheller (Fig. 1) that was developed at the same department was used for the evaluation.

\section{The experimental procedure}

$5 \mathrm{~kg}$ of snake gourd seed was steeped in distil water for a specified time $(10,20,30,40$ and 50 minutes). The seeds were removed after the specified time and then spread in a steel tray in about $2.5 \mathrm{~cm}$ bed thickness and dried in an oven at a specified temperature $(60,70$, 80,90 , and $100^{\circ} \mathrm{C}$ ) with uniform drying time of 20 minutes each. The samples were then shelled and separated into shelled, unshelled and broken kernel which was used to calculate the shelling efficiency of the machine.

\section{Evaluation of the machine}

The effect of hydrothermal pretreatments of snake gourd seed on shelling was studied under the following headings: Effect of Soaking Time and Seed Drying Temperature on the Shelling efficiency of the machine, percentage unshelled and percentage broken of kernel.

\section{Machine efficiency}

The effect of hydrothermal pretreatment on seed shelling efficiency of the machine was calculated from Equation 1 adapted from (18).

$$
M_{E}=\frac{P_{k}}{K} \times 100
$$

Where $M_{E}$ is machine efficiency $(\%), P_{k}$ is percentage kernel recovery, and $\mathrm{K}$ represents the percentage of kernel in seed at the time of shelling.

$K=\frac{M_{s}}{M_{K}} \times 100$

Where $\mathrm{k}$ is the percentage of kernel in seed at 
time of shelling,

$M_{s}$ is mass of seed in $100 \mathrm{~g}$ and $M_{k}$ is the mass of kernel in $100 \mathrm{~g}$

Note: $\mathrm{k}$ was found to be $54.3 \%$

\section{Percentage of unshelled kernel}

Equation 3 was used to calculate the percentage unshelled.

$P_{u s}=\frac{M_{u s}}{M_{s}}$

Where $P_{u s}$ is percentage unshelled (\%) $M_{u s}$ is mass of unshelled seed $(\mathrm{g})$ and $M_{s}$ is total mass of seed $(\mathrm{g})$

\section{Percentage of broken kernel}

To calculate the broken percentage Equation 4 was used

This was calculated from Equation

$T_{B}=\frac{M_{C}}{M_{C}+M_{B}} \times 100$

Where:

$T_{B}$ is Percentage shelled

$\mathrm{M}_{\mathrm{B}}$ is mass of whole cotyledons

$\mathrm{M}_{\mathrm{C}}$ is mass of broken cotyledon

\section{Experimental design}

The two factors selected for the hydrothermal pretreatment of seeds before shelling are soaking time (which resulted in differential moisture content) and seed drying temperature. Table 1 shows the five-level two factor that was used for the evaluations. These factors were used in investigating the shelling efficiency of the machine.

\section{Statistical analysis}

The Design Expert version 6.0.8 of 2002 was used as statistical tool to evaluate main and the interactive effects of these factors on both the shelling and breakage percentage of the machine. Response surface methodology (RMS) was used because of its advantages which include reduction of experimental runs needed to give adequate information for statistical acceptability results, also its ability to assess the relationship between the responses and the independent variables and define the effect of the independent variables, alone or in combinations. The advantages also include comprehensive experimental design and mathematical modeling through the partial regression fitting of the mathematical modeling. The software was also used to determine the coefficient of determination for the models. Excel 2013 was used to draw histogram to show the relationship between the two factors.

\section{Results and Discussion}

Effect of hydrothermal pretreatment of snake gourd seed on shelling efficiency of an impact snake gourd shelling machine

The results of the effect of soaking time and seed drying temperature pretreatment on shelling efficiency and breakage percentage of an impact sheller, design at Ladoke Akintola University of Technology, Ogbomoso is as presented below.

Effect of Soaking Time and seed drying temperature on shelling Efficiency of the machine

The results of the experiment on the effect of soaking time on the decorticating efficiency of the machine were as shown in Table 2. The decorticating efficiency of the machine was observed to increase as the soaking time and seed drying temperature increased (Fig. 2). The highest decorticating efficiency of $82.11 \%$ was observed when the soaking time was 50 minutes, seed drying temperature of $100{ }^{\circ} \mathrm{C}$ and machine speed of 461rpm, while 
the lowest decorticating efficiency of $47.3 \%$ was recorded at 10 minutes soaking time, 60 ${ }^{\circ} \mathrm{C}$ seed drying temperature and 461rpm machine speed. These results follows the same trend as reported by (19), who recorded efficiency of $71 \%$ at $7 \mathrm{~min}$. of soaking time and $54 \%$ efficiency at $5 \mathrm{~min}$. of soaking time. Also, (12) recorded the highest decorticating efficiency of $70.14 \%$ at 20 min. soaking time and lowest decorticating efficiency of $37.87 \%$ at 0 min of soaking time. The results of the experiments showed that as the hydrothermal pre-treatment increased the shelling efficiency of the machine also increased

Statistical analysis of the effect of hydrothermal pretreatment on the efficiency of the machine

The results of the experiments were fixed into Design Expert version 6.0.8 software for statistical analysis. The analysis showed that the two factors investigated (soaking time and seed drying temperature) and their interactions were significant $(\mathrm{p}<0.05)$ (Table $3)$ on the shelling efficiency.

The empirical model relating the soaking time and seed drying temperature to predict the shelling efficiency of the machine is as presented in Equation 5.

$S_{E}=-0.15186+0.10076 S_{T}+$

$0.81685 D_{T}+0,3758 \times 10^{-3} D_{T} S_{T}$

$\left(\mathrm{R}^{2}=0.8435\right)$

Where,

$S_{E}$ is shelling efficiency (\%)

$D_{T}$ is drying temperature $(\circ \mathrm{C})$

$S_{T}$ is soaking time (min.)

\section{Effect of drying temperature and soaking} time on the percentage seed unshelled

The results of the experiment show that the percentage unshelled varies inversely with seed drying temperature and soaking time.
The highest unshelled (49.1\%) was observed when the soaking time was $10 \mathrm{~min}$. at $60{ }^{\circ} \mathrm{C}$ drying temperature while the lowest percentage unshelled $(6.4 \%)$ was recorded at 50 minutes soaking time when the seed drying temperature was $100{ }^{\circ} \mathrm{C}$ at $461 \mathrm{rpm}$ hammer speed. The higher the soaking time and seed drying temperature the lower the percentage unshelled of the machine (Table 4). The percentage unshelled increased as the soaking time and seed drying temperature reduced (Fig. 3). This was in agreement with the report of (20) that reported highest unshelled efficiency $(13.5 \%)$ for canola seeds when soaked in distilled water for 100 minutes followed by hot air drying at $65^{\circ} \mathrm{C}$. Also, (21) recorded the highest percentage of undepulped seed at $9 \%$ at 15 minutes of soaking time, while the lowest percentage of undepulped seed was $1 \%$ at 75 minutes of soaking time.

Statistical analysis of the effect of hydrothermal pretreatment on the percentage unshelled of the machine

The results of the experiments were fixed into Design Expert version 6.0.8 software for statistical analysis. The analysis showed that the two factors investigated (soaking time and seed drying temperature) and their interactions were significant $(\mathrm{p}<0.05)$ (Table 5 ) on the percentage unshelled. The empirical model relating the soaking time and seed drying temperature to predict the percentage unshelled of the machine is as presented in Equation 6.

$$
\begin{gathered}
P_{U}=96.74-0.02003 S_{T}-0.7731 D_{T}- \\
2.4187 \times 10^{-3} D_{T} S_{T} \\
\left(\mathrm{R}^{2}=0.9925\right)(6)
\end{gathered}
$$

Where,

$P_{u}$ is percentage broken (\%)

$D_{T}$ is drying temperature $\left({ }^{\circ} \mathrm{C}\right)$

$S_{T}$ is soaking time (min.) 
Table.1 Five-level, two factors hydrothermal pre-treatment on snake gourd decortication

\begin{tabular}{|l|l|l|l|l|l|}
\hline Factors & \multicolumn{5}{|c|}{ Levels } \\
\hline Soaking Time (min.) & 10 & 20 & 20 & 40 & 50 \\
\hline Drying Temperature $\left({ }^{\circ} \mathbf{C}\right)$ & 60 & 70 & 80 & 90 & 100 \\
\hline
\end{tabular}

Table.2 Effect of soaking time and seed drying temperature on the shelling efficiency of the machine

\begin{tabular}{|l|l|l|l|l|l|l|}
\hline Evaluation & $\mathbf{D}_{\mathbf{T}}\left({ }^{\circ} \mathbf{C}\right)$ & \multicolumn{5}{|c|}{ Soaking Time (minutes) } \\
\hline & & 10 & 20 & 30 & 40 & 50 \\
\hline Shelling efficiency & 60 & 47.3 & 48.8 & 50.33 & 51.88 & 54.56 \\
\hline & 70 & 54.1 & 55.63 & 57.1 & 60.10 & 60.43 \\
\hline & 80 & 61.70 & 63.23 & 64.30 & 66.54 & 67.65 \\
\hline & 90 & 68.32 .33 & 69.83 & 70.32 & 71.89 & 74.33 \\
\hline & 100 & 75.18 & 76.86 & 78.44 & 69.88 & 82.11 \\
\hline
\end{tabular}

Average of three experimental runs

Table.3 Analysis of variance table for response surface model of the effect of the seed hydrothermal pretreatment on shelling efficiency of the machine

\begin{tabular}{|l|l|l|l|l|l|l|}
\hline Source & & Sum of Squares & DF & Mean Squares & F Value & Prob > F \\
\hline Model & & 1714.75 & 3 & 571.59 & 4288.62 & $<0.0001$ \\
\hline & DT & 110.70 & 1 & 110.70 & 830.57 & $<0.0001$ \\
\hline & SA & 1597.22 & 1 & 1597.22 & 11985.89 & $<0.0001$ \\
\hline & DTSA & 1.21 & 1 & 1.21 & 9.08 & $<0.0146$ \\
Residual & & 1.20 & 9 & 0.13 & & \\
\hline Cor Total & & 1715.96 & 12 & & & \\
\hline
\end{tabular}

Table.4 Effect of soaking time and seed drying temperature on the percentage unshelled of the machine

\begin{tabular}{|l|l|l|l|l|l|l|}
\hline Evaluation & $\mathbf{D}_{\mathbf{T}}\left({ }^{\circ} \mathbf{C}\right)$ & \multicolumn{5}{|c|}{ Soaking Time (minutes) } \\
\hline & & 10 & 20 & 30 & 40 & 50 \\
\hline \% Unshelled & 60 & 49.1 & 47.4 & 55.4 & 54.0 & 41.77 \\
\hline & 70 & 40.13 & 39.00 & 37.20 & 35.3 & 34.5 \\
\hline & 80 & 32.30 & 29.10 & 29.00 & 26.2 & 24.44 \\
\hline & 90 & 24.2 & 23.3 & 19.5 & 18.5 & 15.76 \\
\hline & 100 & 17.6 & 14.3 & 11.2 & 9.07 & 6.4 \\
\hline
\end{tabular}

Average of three experimental runs 
Table.5 Analysis of variance table for response surface model of the effect of the seed hydrothermal pretreatment on percentage seed broken of the machine

\begin{tabular}{|l|l|l|l|l|l|l|}
\hline Source & & Sum of Squares & DF & Mean Squares & F Value & Prob > F \\
\hline Model & & 1674.09 & 3 & 558.03 & 1036.40 & $<0.0001$ \\
\hline & DT & 113.63 & 1 & 113.63 & 211.04 & $<0.0001$ \\
\hline & SA & 1551.09 & 1 & 1551.09 & 2880.77 & $<0.0001$ \\
\hline & DTSA & 3.74 & 1 & 3.74 & 6.95 & $<0.0270$ \\
\hline Residual & & 4.85 & 9 & 0.54 & & \\
\hline Cor Total & & 1678.94 & 12 & & & \\
\hline
\end{tabular}

Table.6 Effect of soaking time and seed drying temperature on percentage breakage of the machine

\begin{tabular}{|l|l|l|l|l|l|l|}
\hline Evaluation & $\left.\mathbf{D}_{\text {T }}{ }^{\circ}{ }^{\circ} \mathbf{C}\right)$ & \multicolumn{5}{|c|}{ Soaking Time (minutes) } \\
\hline & & \multicolumn{5}{|c|}{} \\
\hline & & 10 & 20 & 30 & 40 & 50 \\
\hline $\begin{array}{l}\text { Breakage } \\
\text { percentage }\end{array}$ & 60 & 6.1 & 5.8 & 5.4 & 5.0 & 5.0 \\
\hline & 70 & 6.8 & 6.3 & 6.0 & 5.8 & 5.5 \\
\hline & 80 & 7.5 & 6.8 & 6.6 & 6.5 & 6.5 \\
\hline & 90 & 9.9 & 8.3 & 7.8 & 7.6 & 7.5 \\
\hline & 100 & 11.9 & 10.8 & 10.6 & 9.9 & 9.6 \\
\hline
\end{tabular}

Average of three experimental runs

Table.7 Analysis of variance table for response surface model of the effect of the seed hydrothermal pretreatment on percentage broken of the machine

\begin{tabular}{|l|l|l|l|l|l|l|}
\hline Source & & Sum of Squares & DF & Mean Squares & F Value & Prob $>$ F \\
\hline Model & & 47.10 & 5 & 9.42 & 104.19 & $<0.0001$ \\
\hline & DT & 3.03 & 1 & 3.03 & 33.49 & $<0.0007$ \\
\hline & SA & 33.01 & 1 & 33.01 & 365.09 & $<0.0001$ \\
\hline & DT2 & 0.26 & 1 & 0.26 & 2.92 & $<0.1313$ \\
\hline & WT2 & 3.34 & 1 & 3.34 & 36.91 & $<0.0005$ \\
\hline & DTSA & 0.36 & 1 & 0.36 & 3.98 & $<0.0802$ \\
\hline Residual & & 0.63 & 7 & 0.09 & & \\
\hline Cor Total & & 47.73 & 12 & & & \\
\hline
\end{tabular}


Fig.1 The snake gourd sheller

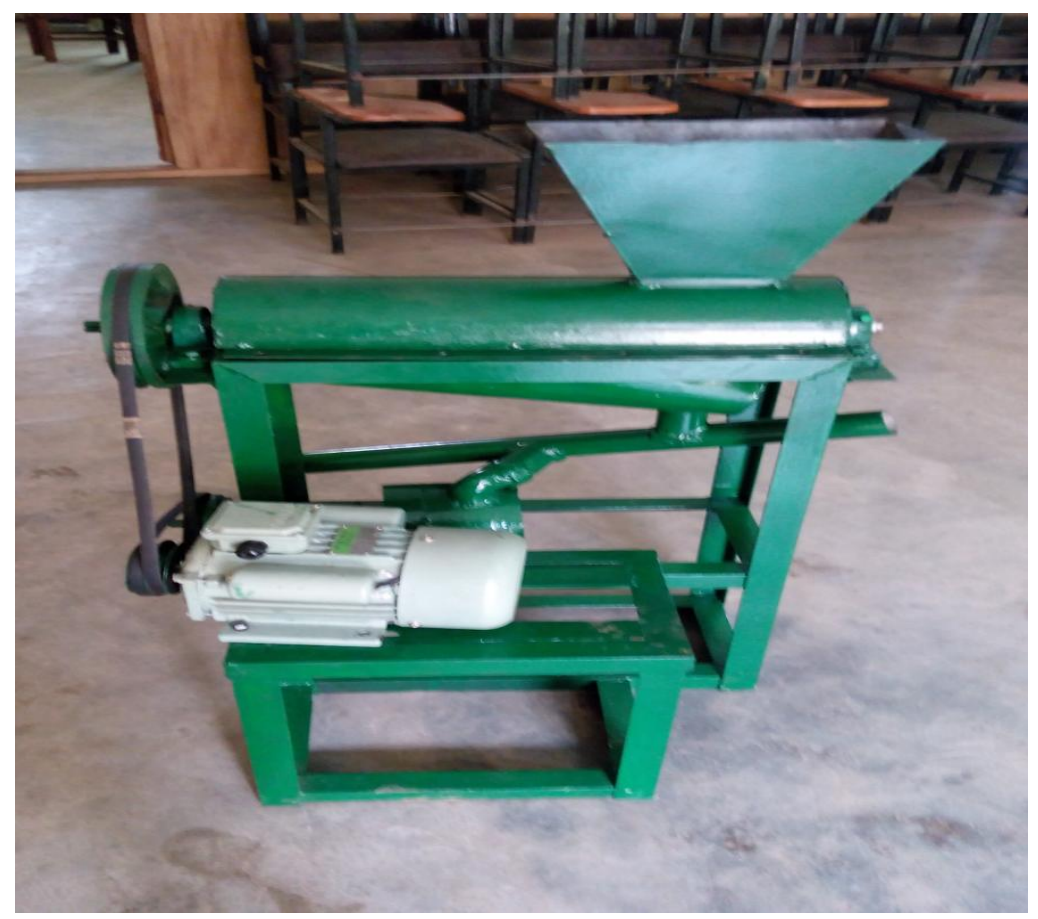

Fig.2

$\square 60\left({ }^{\circ} \mathrm{C}\right) \quad 70\left({ }^{\circ} \mathrm{C}\right) \quad \square 80\left({ }^{\circ} \mathrm{C}\right)-90\left({ }^{\circ} \mathrm{C}\right) \quad \square 100\left({ }^{\circ} \mathrm{C}\right)$

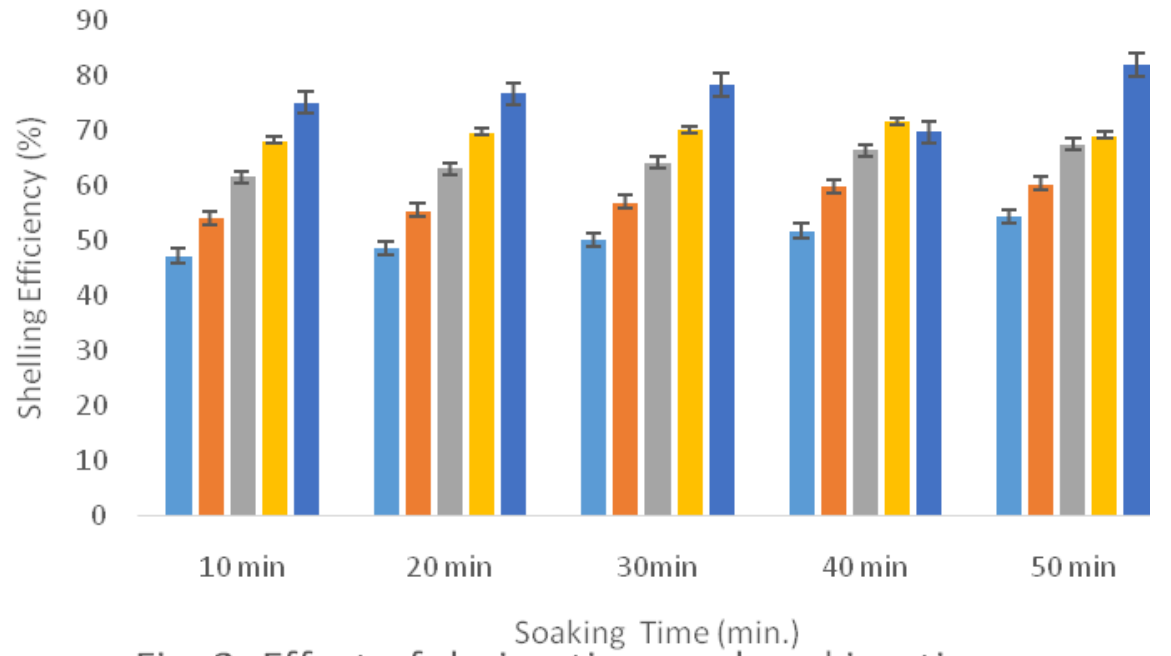

Fig. 2: Effect of drying time and soaking time on the shelling efficiency of snake gourd seed 
Fig.3

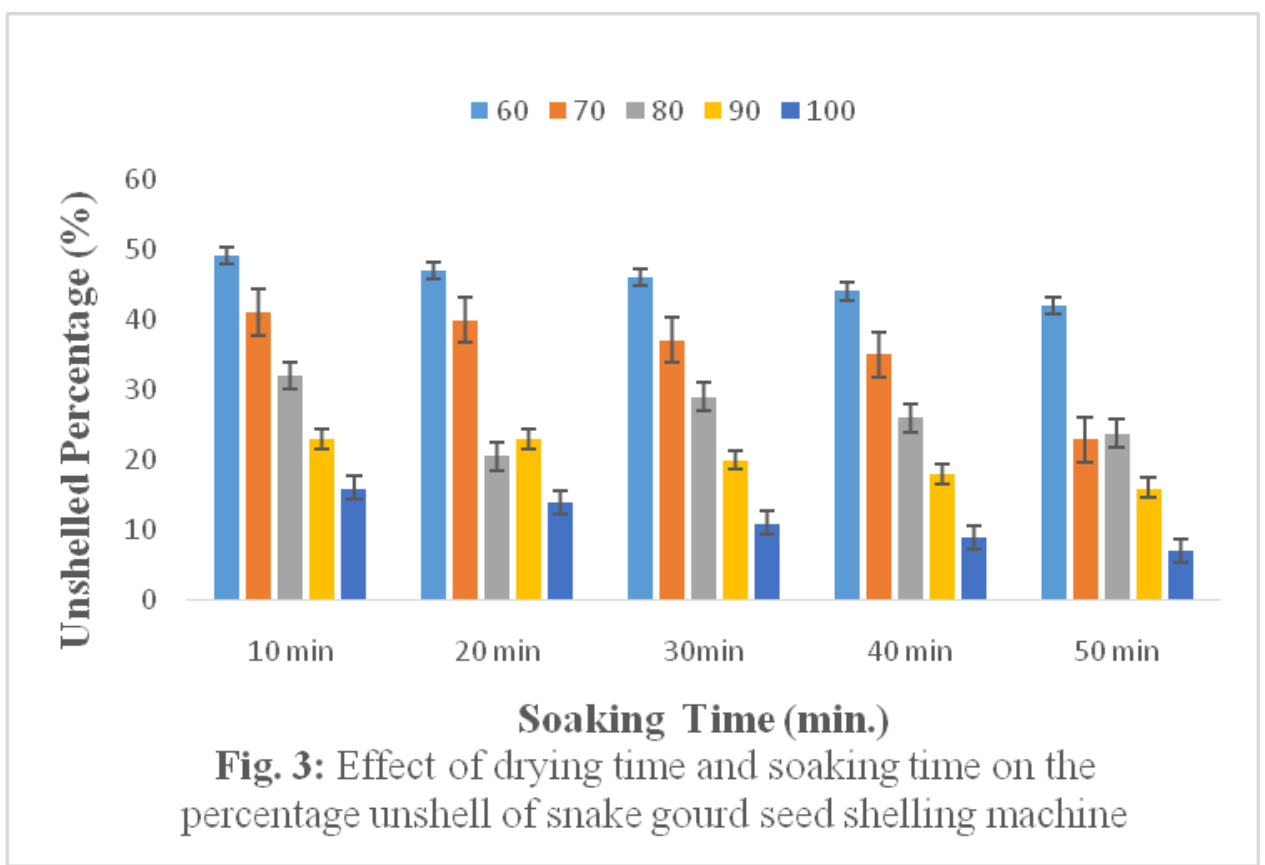

\section{Fig.4}
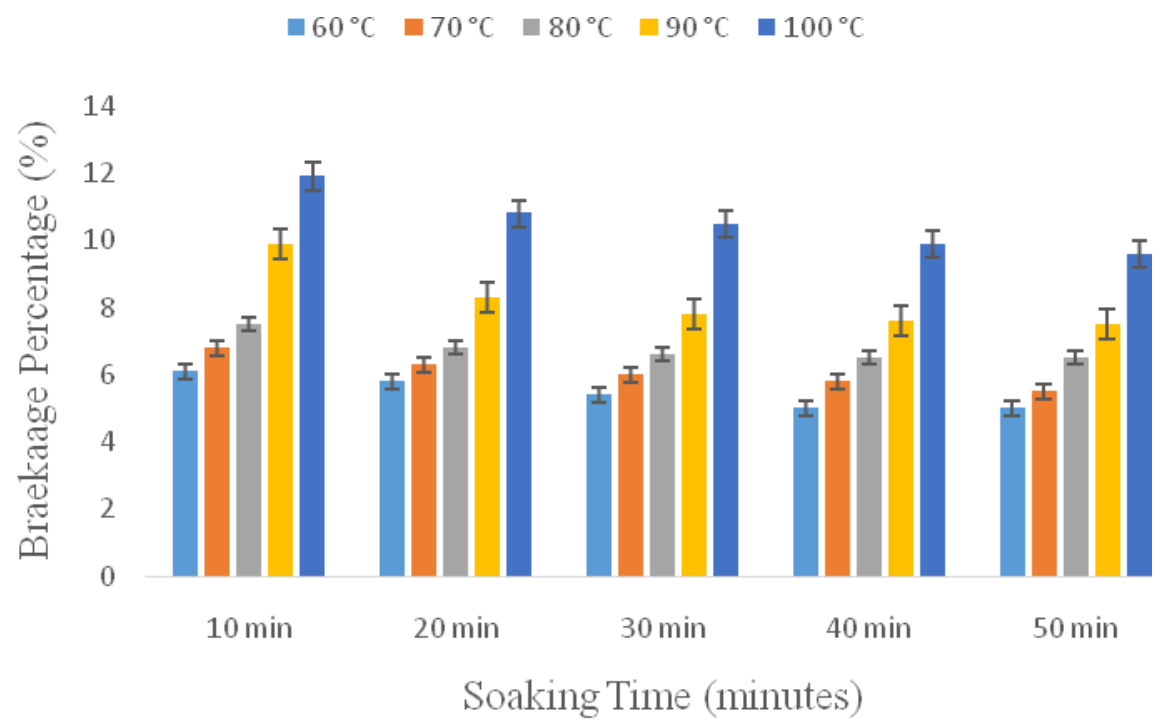

Fig 4:Effect of soaking time and seed dring temperature on percentage brakage 
Fig.5 Complexity plot of NADH

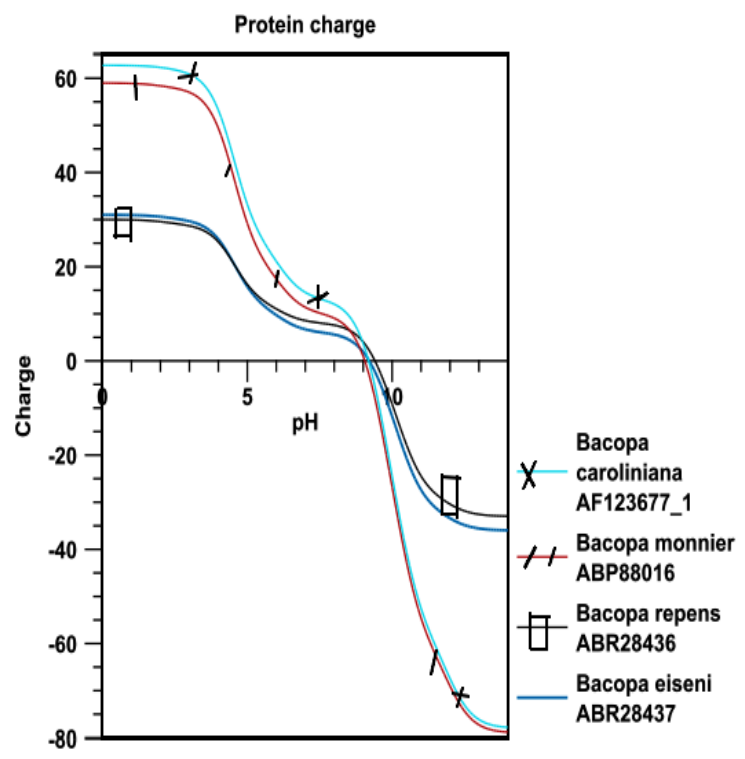

Effect of drying temperature and soaking time on the percentage seed brakeage

The results of the experiment on the effect of hydrothermal pretreatment on the broken percentage of shelled snake gourd seed was as presented in Table 6. The pecentage broken kernel decreases as the soaking time increases. The least broken percentage was achieved when soaking time was 50 minutes and drying temperature was $60^{\circ} \mathrm{C}$ while the highest broken percentage was recorded when the soaking time was 60 minutes. This result was in agreement with the report of (22) for Jatropha fruit decortications and (23) for shea butter craking they both reported decrease in broken percentage with increase in moisture. It was observed that the higher the seed drying temperature the higher the broken percentage (Fig. 4).

Statistical analysis of the effect of hydrothermal pretreatment on the broken percentage of the machine

The results of the experiments on the effect of drying temperature and soaking time on the broken percentage during shelling of snake gourd were fixed into Design Expert version 6.0.8 software for statistical analysis. The analysis showed that the two factors investigated (soaking time and seed drying temperature) and their interactions were significant $(\mathrm{p}<0.05)$ (Table 7).

The regression model representing the relationship between wetting time and drying temperature is as shown in Equation 7.

$P_{B}=16.669-0.0258 W_{T}-0.3569 D_{T}+$ $8.4829 \times 10^{-4} W_{T}{ }^{2}+3.1691 \times 10^{-3} D_{T}{ }^{2}-$ $7.5 \times 10^{-4} D_{T} S_{T}$

$\left(\mathrm{R}^{2}=0.9867\right) \quad(7)$

Where, $P_{B}$ is percentage broken $(\%)$ $D_{T}$ is drying temperature $\left({ }^{\circ} \mathrm{C}\right)$ $S_{T}$ is soaking time (min.)

In conclusion, the effect of seed pretreatment on shelling efficiency and broken percentage was evaluate using hydrothermal pretreatment (soaking time and seed drying temperature). The result shows that both the soaking time and the drying temperature were very 
significant on shelling efficiency, unshell percentage and broken percentage investigated. It is there for recommended that during optimization of the snake gourd seed shelling hydrothermal pretreatment of the seed should be taking into consideration.

\section{References}

1. Kissan.M, (2006) Snake gourd (Trichosanth cucumerina) of seed and cultivation, weed Management, harvesting disease and pest management. Farmer database, pp. 110.

2. Robinson R.W. and Decker-Walkers, D.S, (1997): Appendix common cucurbit name and their scientific equivalents in cucurbits. $\mathrm{CAB}$ international, USA.

3. Idowu D O. (2015) A study on the effect of washing kernel on yield color and a rheological properties of snake gourd oil. Journal of Agricultural Technology. 11(4: 811-822).

4. Folarin. O.M., Enikanoselu, ON. (2010).Evaluation of the effect of temperature on the stability of metal soaps Trichosanthes cucumerina seed oil. Journal of Applied, Science and Environment, 14 (3): 69-79.

5. Figuiredo, A.K., Rodriguez, L.M., Lindstrom L.I., Riccobene I.C., and Nolasco, S.M. (2013), performance analysis of a de-hulling system for safflower grains. Industrial crops and product, 43(5): 311-317.

6. Figuiredo, A.K., Rodriguez, L.M., Riccobene I.C., and Nolasco, S.M. (2014). Analysis of the performance of a dehulling system for confectionary sunflower seeds, Food and Nutrition science, 5(6): 541-548.

7. Kate, A.E, Lohani, U.C,. Pandey J.P Shahi N.C. Sarkar A. (2014). Traditional and mechanical Method of the oil extraction from wild apricot kernel: a comparative study. Res. J. Chem. Env. Sci. Vol 2 (2) April. 54-60.

8. Wim, D.G., Maes, J., Smons, B., Balshaw.,C and Miles, D. (2007). Improved yield and biodiesel quality from Jatropha curcas by optimized seed processing and oil pre- treatment. Proceedings of the AOCS. International congress on biodiesel, Viena, Austria. Pg. 5-7.

9. Oluwole, F.A. Abudulram, A.T., Aviara N.A., and Nana, S.N. (2012). Traditional method of Extracting castor oil. Continental Journal of Engineering science. 7 (2) 6-10.

10. Ting, R.P., Peralta E.V.C., Elauria, J.C., 2012. Design, fabrication and optimization of jatropha sheller. International journal of optimization and control theories and application, 2 (2): 113-127.

11. Nunneley, J.L., Faulkner, W.B., Shimek, M.V., Holt, G.A., Wedegaertner, T.C. 2012. Optimization of a cottonseed dehulling process to yield intact seed meals. Applied Engineering in Agriculture, 29 (5):613619.

12. Aremu, A.K., Adeniyi, A.O. and Fadele, O.K. 2015. Development and performance of a jatropha seed shelling machine based on seed moisture content. Journal of biosystem Engineering, 40(2): 137-144.

13. Fadele, O.K. and Aremu, A.K. (2017). Performance evaluation of some tangential impact shelling device for moringa seed shelling. Agricultural Engineering CIGR.E Journal, 19(4); 170-180.

14. Malleshl N.G., (2007). Nutritional and technical features of ragi (finger millet) and processing for value addition in food uses of small millet and avenues for further processing and value addition. Bangalore project coordinating 
cell. All India coordinated small millet improvement project ICAR, UAS,GKVK. Pg 9-19.

15. Kimura, T., Bhattacharya, K.R., Ali, S.Z (1993). Effect of processing condition on the colour intensity of parboiled rice. Journal of Science, AgricStruct. 24:23-30.

16. Idowu, D.O. and Owolarafe, O.K. (2013) A study of some hydroaerodynamic properties of snake gourd (Trichosantes cucumerina. L) seed, kernel and chaff. Journal of Agricultural Technology, 9(7):1691-1701.

17. Idowu D.O. and Owolarafe, O.K. (2014). Physical properties of snake gourd seed (Trichosantes cucumerina $\mathrm{L}$ ) relevant in grading and separation. Agric. Eng. Int: CIGR Ejournal, 16 (1): 303-312.

18. Amoah, F. (2013). Modification and Evaluation of a groundnut cracker for cracking Jatropha seeds. A M.Sc. thesis at the Department Agricultural Engineering, Kwame Nkrumah University of science and Technology, Ghana.

19. Olusegun, A.D. and Adekunle A.S. (2008). The design, construction and testing of melon sheller. Global journal of engineering and technology 1 (4):360-368).

20. Mohamadzadeh, J., Sadeghi-Mahoonak, A., Yaghbani M. and Aalami M., (2009). Effect of Hydrothermal pretreatment of canola seed on dehulling efficiency and oil quality. World journal of dairy \& food sciences 4(1) 14-18.

21. Olaoye J.O. (2012). Development of small scale Equipment for depulpping locust bean seeds. International Journal of Engineering and Technology, 11(6): 173-186.

22. Pradhan, R.C., Naik, S.N., Bhatnagar, N and Vijay, V.K. (2010). Design, development and testing of hand operated decorticator for jatropha fruit. Applied Energy 87 (3):762- 768.

23. Oluwole, F.A., Aviara, N.A and Haque M.A. 2004. Development and performance evaluation test of sheanut cracker. Journal of food Engineering 65 (1): $117-123$.

24. Oluwole, F.A., Aviara, NA., Umar, B.,and Mohammed, A.B. (2015). Influence of variety and pre-treatment on oil properties of mechanically expressed castor oil. Journal of Engineering Technology and innovation. 4 (1):1-9.

25. C.D.K. Cook, B.J. Gupta, E.M.Rix, J. Scheller, and M. Serrz, Water plants of the world, Jurh, The Hague. Court, A. B. (1957), Sundry notes on three Victori, 1974.

26. A. Agrawal, M.N. Pandey, and G.P. Dubey, Management of mental deficiency by an indigenous drug, Brahmi (Bacopa monniera), Pharmacopsychoecologia., Vol.6(1), pp. 1-5, 1993.

\section{How to cite this article:}

Idowu, D.O., S.A. Olaoye, E.O. Owolabi and Adebayo, J.M. 2019. Effect of Hydrothermal PreTreatment on Snake Gourd Seed Shelling. Int.J.Curr.Microbiol.App.Sci. 8(02): 1848-1858. doi: https://doi.org/10.20546/ijcmas.2019.802.217 